\title{
Effect of INM on Yield, Quality and Economics in Foxtail Millet (Setaria italica L.) in Black Soil
}

\author{
Raviraja $^{1 *}$, S. R. Balanagoudar ${ }^{1}$, S. N. Bhat ${ }^{1}$, M. V. Ravi ${ }^{1}$ and G. S. Yadahalli ${ }^{2}$ \\ ${ }^{1}$ Department of soil science and agricultural chemistry, ${ }^{2}$ Department of Agronomy, \\ University of Agricultural Sciences, Raichur - 584104, Karnataka, India \\ *Corresponding author
}

\begin{tabular}{l} 
Key w o r d s \\
$\begin{array}{l}\text { Foxtail millet, } \\
\text { Growth and yield } \\
\text { attributes, Grain } \\
\text { yield, Stover yield }\end{array}$ \\
\hline Article Info \\
\hline $\begin{array}{l}\text { Accepted: } \\
\text { 15 February } 2020 \\
\text { Available Online: } \\
\text { 10 March } 2020\end{array}$ \\
\hline
\end{tabular}

A field experiment was conducted at Main Agricultural Research Station, Raichur, during kharif 2018-19 to study the integrated nutrient management on Foxtail millet (Setaria italic L.) in black soil. The experiment was laid out with eleven treatments replicated three times in randomized block design. Among all the treatments, application of RDF $+2.5 \mathrm{t} \mathrm{ha}^{-1}$ Vermicompost + Bio-fertilizer + Foliar spray of 19:19:19 at 15, 30 and 45 DAS significantly recorded grain yield and straw yield were significantly recorded (2414 $\mathrm{kg} \mathrm{ha}^{-1}$ and $6034 \mathrm{~kg} \mathrm{ha}^{-1}$ ) as compared to absolute control and RDF. The treatment also recorded higher gross returns, net returns, and B C ratio (82677 ha ${ }^{-1}, 56097 \mathrm{ha}^{-1}$, and 3.11, respectively). It is concluded that the application of RDF $+2.5 \mathrm{t} \mathrm{ha}^{-1}$ Vermicompost + Bio-fertilizer) + Foliar Spray of 19:19:19 at 15,30 and 45 DAS is the best treatment in rainfed condition to achieve higher yield, net returns and $\mathrm{B} \mathrm{C}$ ratio as compared to RDF and absolute control.

\section{Introduction}

Foxtail millet grown since time immemorial is predominantly self-pollinated crop belonging to family graminae. Under condition of low input management, it grows well and produces more than pearl millet. Foxtail millet is one of the world's oldest cultivated crops. It is also called as famine reserve and it is extensively grown under low rainfall area. Foxtail millet is the second most widely grown species of millet and the most important food crop in East Asia. In India, foxtail millet is important crop in arid and semi-arid regions. In South India, it has been a staple diet among people for a long time and it is a warm season crop, typically grown in late spring season and harvested for grain in 
75-90 days (800-900 $\mathrm{kg} \mathrm{ha}^{-1}$ ). Foxtail millet is commonly known as Navane in Karnataka (Vinall, 1924).

In this context, it is worth to mention that nutrient management through organics plays a major role in maintaining soil health due to buildup of soil organic matter, beneficial microbes and enzymes besides improving soil physical and chemical properties. In a farming system approach, the nutrient needs are met out through recycling process to achieve sustained soil fertility and crop productivity.

The options available on the farm include use of various organic manures viz., FYM, compost, vermicompost, green manures, biofertilizers etc. Nutrient management aims at efficient and judicious use of all the major sources of plant nutrients in an integrated manner to get maximum economic yield without any deleterious effects on physicochemical and biological properties of the soil. Integration of nutrients plays an significant role in better penetration and establishment of sorghum roots, which is responsible for the plant to take up water from deeper layers and to maintain high relative plant water content under soil moisture deficit condition (Jadhao et al., 2002).

\section{Materials and Methods}

The experiment was conducted at Main Agricultural Research Station, Raichur, which is situated between $16^{\circ} 12^{\prime} \mathrm{N}$ latitude and $77^{\circ} 20^{\prime}$ E longitude with an altitude of 389 meters above the mean sea level and is located in Zone-2 of Karnataka. A composite surface $(0-15 \mathrm{~cm})$ soil sample was drawn from the experimental site before initiation of experiment. The soil was air-dried, powdered and passed through $2 \mathrm{~mm}$ sieve and was analyzed for physico-chemical properties. The results and analytical techniques employed for their estimation were given in Table 1. The experiment was conducted with eleven treatments having different sources of organics and recommended dose of fertilizer treatments which were randomly allocated in Randomized Complete Block Design (RCBD) with three replications. the treatment details area

$\mathrm{T}_{1}$ : Absolute control, $\mathrm{T}_{2}$ : RDF (30:15:15 kg $\left.\mathrm{N}: \mathrm{P}_{2} \mathrm{O}_{5}: \mathrm{K}_{2} \mathrm{O} \mathrm{ha}^{-1}\right), \mathrm{T}_{3}: \mathrm{FYM} @ 6 \mathrm{t} \mathrm{ha}^{-1}, \mathrm{~T}_{4}$ : Vermicompost @ 2.5 t ha ${ }^{-1}, \mathrm{~T}_{5}$ : RPP (RDF+FYM @6 tha ${ }^{-1}+$ Bio-fertilizer), $\mathrm{T}_{6}$ : RPP (RDF+ Vermicompost @ $2.5 \mathrm{t} \mathrm{ha}^{-1}+$ Bio-fertilizer), $\mathrm{T}_{7}$ : RDF+ Foliar spray of 19:19:19@1\% at 15, 30 and 45 DAS, T8: FYM @ $6 \mathrm{t} \mathrm{ha}^{-1}+$ Foliar spray of 19:19:19@ $1 \%$ at 15,30 and 45 DAS, T9: Vermicompost @ $2.5 \mathrm{t} \mathrm{ha}^{-1}+$ Foliar Spray of 19:19:19 @ 1\% at 15, 30 and $45 \mathrm{DAS} \mathrm{T}_{10}$ : RPP (RDF+ FYM @ $6 \mathrm{t} \mathrm{ha}^{-1}+$ Bio-fertilizer) + Foliar Spray of 19:19:19@1\% at15, 30 and 45 DAS, T 11 : RPP (RDF+ Vermicompost @ $2.5 \mathrm{t} \mathrm{ha}^{-1}+$ Bio-fertilizer) + Foliar Spray of 19:19:19 @ 1 $\%$ at 15,30 and 45 DAS.

Note: Recommended Package Of Practices : RDF (30:15:15 kg N, $\mathrm{P}_{2} \mathrm{O}_{5}$ and $\mathrm{K}_{2} \mathrm{O}$ ha $^{-1}$ ), FYM @ $6.0 \mathrm{t} \mathrm{ha}^{-1}$, Biofertilizer ( Azospirillum @ $\left.200 \mathrm{~g} \mathrm{ha}^{-1}\right)$ soil application.

The good quality seeds of foxtail millet variety (HN-46) were sown with spacing of $30 \times 10 \mathrm{~cm}$. Five plants from the net plot area were randomly selected and they were tagged to record the periodical observations at 30, 60 days after sowing and also at the time of harvest.

Protein content in the seeds of foxtail millet was estimated by Broad Ford method by using CBB (Comassie brilliant blue) colour as a colouring agent and readings were recorded in spectrophotometer at wavelength $595 \mathrm{~nm}$ and results expressed in per cent.the gross returns, Net returns and $\mathrm{BC}$ ratio is worked out. 


\section{Results and Discussion}

\section{Grain yield}

There was a significant difference in the grain yield, stover yield and Harvest index of foxtail millet due to different treatment combination and the results are shown in the Table 2 and Fig. 1.

Application of RDF (30:15:15 kg $\left.\mathrm{N}: \mathrm{P}_{2} \mathrm{O}_{5}: \mathrm{K}_{2} \mathrm{O} \mathrm{ha}^{-1}\right)+2.5 \mathrm{t} \mathrm{ha}^{-1}$ Vermicompost + Bio-fertilizer) + Foliar spray of 19:19:19 @ $1 \%$ at 15,30 and 45 DAS $\left(\mathrm{T}_{11}\right)$ recorded significantly higher grain yield $\left(2414 \mathrm{~kg} \mathrm{ha}^{-1}\right)$ and it was on par with treatments $\mathrm{T}_{10}$ where $\operatorname{RDF}\left(30: 15: 15 \mathrm{~kg} \mathrm{~N}: \mathrm{P}_{2} \mathrm{O}_{5}: \mathrm{K}_{2} \mathrm{O} \mathrm{ha}^{-1}\right)+6 \mathrm{tha}^{-1}$ FYM + Bio-fertilizer) + Foliar spray of 19:19:19@1\% at 15, 30 and 45 DAS (2252 $\left.\mathrm{kg} \mathrm{ha}^{-1}\right)$. However, lower grain yield $(853 \mathrm{~kg}$ $\left.h^{-1}\right)$ was obtained in $\left(T_{1}\right)$ absolute control treatment.

Higher grain yield was noticed with application of RDF (30:15:15 kg N: $\mathrm{P}_{2} \mathrm{O}_{5}: \mathrm{K}_{2} \mathrm{O}$ $\left.\mathrm{ha}^{-1}\right)+2.5 \mathrm{t} \mathrm{ha}^{-1}$ Vermicompost + Biofertilizer + Foliar spray of 19:19:19 @ 1\% at 15,30 and 45 DAS (2414 $\left.\mathrm{kg} \mathrm{ha}^{-1}\right)$. It might be due to the adequate amount of nutrients availability both macro and micro nutrient results from treatment effect which enhanced the crop growth. The increased availability of $\mathrm{N}, \mathrm{P}, \mathrm{K}, \mathrm{Zn}, \mathrm{Cu}, \mathrm{Mn}$ and $\mathrm{Fe}$ as well as the synergistic effect between organic and inorganic forms of nutrients and formation of stable complexes with humic substances supplied through poultry manure in rice crop (Dosani et al., 1999 in groundnut crop and Balaji and Yakadri 2004). The combined application of organic and inorganic sources provided greater availability of nutrients for the development of vegetative structures and increased the number of grain, grain weight and resulted in higher grain yield (Uddin et al., 2008).

\section{Stover yield}

Significantly higher stover yield was recorded in the treatment which received RDF $\left(30: 15: 15 \mathrm{~kg} \mathrm{~N}: \mathrm{P}_{2} \mathrm{O}_{5}: \mathrm{K}_{2} \mathrm{O} \mathrm{ha}^{-1}\right)+2.5 \mathrm{tha}^{-1}$ Vermicompost + Bio-fertilizer) + Foliar spray of 19:19:19@1\% at 15,30 and 45 DAS $\left(6034 \mathrm{~kg} \mathrm{ha}^{-1}\right)$. However, it was on par with treatment which received RDF (30:15:15 kg $\mathrm{N}: \mathrm{P}_{2} \mathrm{O}_{5}: \mathrm{K}_{2} \mathrm{O}$ ha $\left.^{-1}\right)+6 \mathrm{t} \mathrm{ha}^{-1} \mathrm{FYM}+$ Biofertilizer) + Foliar spray of 19:19:19 @ 1\% at 15, 30 and 45 DAS $\left(\mathrm{T}_{10}\right)\left(5775 \mathrm{~kg} \mathrm{ha}^{-1}\right)$. Significantly lower straw yield $\left(2230 \mathrm{~kg} \mathrm{ha}^{-1}\right)$ was obtained in absolute control $\left(\mathrm{T}_{1}\right)$.

Higher the stover yield was recorded with application of RDF (30:15:15 kg N: $\mathrm{P}_{2} \mathrm{O}_{5}: \mathrm{K}_{2} \mathrm{O}$ $\left.\mathrm{ha}^{-1}\right)+2.5 \mathrm{t} \mathrm{ha}^{-1}$ Vermicompost + Biofertilizer) + Foliar spray of 19:19:19 @ 1\% at 15, 30 and 45 DAS $\left(6034 \mathrm{~kg} \mathrm{ha}^{-1}\right)$. This was mainly because of increasing in the levels and source of nutrients with organic manures significantly increased the straw yield of hybrid rice which might due to the integrated effect of $\mathrm{N}, \mathrm{P}$ and $\mathrm{K}$ levels and different sources of organic manures on $\mathrm{N}, \mathrm{P}$ and $\mathrm{K}$ availability and their uptake as well as grain and straw yield of hybrid rice. The supply of inorganic and organic manures increased the grain and straw yield of hybrid rice. The addition of organic manure might influence $\mathrm{N}, \mathrm{P}$ and $\mathrm{K}$ availability by maintaining good physical condition of soil for plant growth and yield. The increase in straw yield of hybrid rice with combined application of fertilizer and manure was reported by Rahman et al., (2005), Gupta et al., (2006) and Bajpai et al., (2006).

\section{Harvest index}

Higher harvest index $(33.20 \%)$ was recorded with application of FYM $\left(6 \mathrm{t} \mathrm{ha}^{-1}\right)$. However, lower harvest index was recorded in $\mathrm{T}_{6}(27.10$ $\%)$ as compared to absolute control $\left(\mathrm{T}_{1}\right)$. 
Table.1 Grain yield, stover yield and harvest index of foxtail millet as influenced by nutrient management practices

\begin{tabular}{|c|c|c|c|}
\hline Treatment & $\begin{array}{c}\text { Grain } \\
\text { yield } \\
\left(\mathrm{kg} \mathrm{ha}^{-1}\right)\end{array}$ & $\begin{array}{c}\text { Stover } \\
\text { yield } \\
\left(\begin{array}{c}\text { kg ha } \\
1\end{array}\right)\end{array}$ & $\begin{array}{c}\text { Harvest } \\
\text { index } \\
(\%)\end{array}$ \\
\hline $\mathbf{T}_{1}$ : Absolute control & 853 & 2230 & 27.7 \\
\hline$T_{2}: \operatorname{RDF}\left(30: 15: 15 \mathrm{~kg} \mathrm{ha}^{-1}\right)$ & 1448 & 3534 & 29.1 \\
\hline $\mathrm{T}_{3}:$ FYM $6 \mathrm{t} \mathrm{ha}^{-1}$ & 1285 & 2590 & 33.2 \\
\hline $\mathrm{T}_{4}:$ Vermicompost $2.5 \mathrm{t} \mathrm{ha}^{-1}$ & 1348 & 3469 & 28.0 \\
\hline $\mathrm{T}_{5}: \mathrm{RPP}\left(\mathrm{RDF}+6 \mathrm{t} \mathrm{ha}^{-1} \mathrm{FYM}+\mathrm{Bio}-\mathrm{fertilizer}\right)$ & 1853 & 4530 & 29.0 \\
\hline $\mathrm{T}_{6}: \operatorname{RPP}\left(\mathrm{RDF}+2.5 \mathrm{t} \mathrm{ha}^{-1}\right.$ Vermicompost + Bio-fertilizer $)$ & 2024 & 5458 & 27.1 \\
\hline$T_{7}:$ RDF+ Foliar Spray of 19:19:19 @ $1 \%$ at 15, 30 and 45 DAS & 1595 & 3668 & 30.3 \\
\hline $\begin{array}{l}\text { T8 }: \text { FYM } 6 \mathrm{t} \mathrm{ha}^{-1}+\text { Foliar Spray of 19:19:19 @ } 1 \% \text { at } 15,30 \text { and } \\
45 \text { DAS }\end{array}$ & 1679 & 4261 & 28.3 \\
\hline $\begin{array}{l}\mathrm{T}_{9}: \text { Vermicompost } 2.5 \mathrm{t} \mathrm{ha}^{-1}+\text { Foliar Spray of 19:19:19 @ } 1 \% \text { at } \\
\text { 15, } 30 \text { and } 45 \text { DAS }\end{array}$ & 1838 & 4691 & 28.2 \\
\hline $\begin{array}{l}T_{10}: \text { RPP }\left(\text { RDF + } 6 \mathrm{t} \mathrm{ha}^{-1} \text { FYM+ Bio-fertilizer }\right)+\text { Foliar Spray of } \\
19: 19: 19 @ 1 \% \text { at } 15,30 \text { and } 45 \text { DAS }\end{array}$ & 2252 & 5775 & 28.1 \\
\hline $\begin{array}{l}\mathrm{T}_{11}: \text { RPP }\left(\mathrm{RDF}+2.5 \mathrm{t} \mathrm{ha}^{-1} \text { Vermicompost }+ \text { Bio-fertilizer }\right)+ \\
\text { Foliar Spray of 19:19:19 @ } 1 \% \text { at } 15,30 \text { and } 45 \text { DAS }\end{array}$ & 2414 & 6034 & 28.6 \\
\hline S.Em \pm & 95.19 & 128.60 & 0.01 \\
\hline CD at $5 \%$ & 280.80 & 379.36 & NS \\
\hline
\end{tabular}

Table.2 Protein content of foxtail millet nutrient management practices at harvest stage

\section{Treatment}

Protein

(\%)

$\mathrm{T}_{1}$ - Absolute control

6.14

$T_{2}$ - RDF(30:15:15)

7.63

$\mathrm{T}_{3}$ - FYM 6 t ha $^{-1}$

7.36

$\mathrm{T}_{4}$ - Vermicompost $2.5 \mathrm{tha}^{-1}$

7.50

T 5- RPP (RDF+ $6 \mathrm{t} \mathrm{ha}^{-1}$ FYM + Bio-fertilizer)

8.63

$\mathrm{T}_{6}$ - RPP (RDF+ $2.5 \mathrm{t} \mathrm{ha}^{-1}$ Vermicompost + Bio-fertilizer)

9.13

$\mathrm{T}_{7}-\mathrm{RDF}+$ Spray of 19:19:19 @ $1 \%$ at 15, 30 and 45 DAS

8.31

T - FYM $6 \mathrm{t} \mathrm{ha}^{-1}+$ Spray of 19:19:19 @ $1 \%$ at 15, 30 and 45 DAS $^{1}$

8.50

$\mathrm{T}_{9}$-Vermicompost 2.5 $\mathrm{t} \mathrm{ha}^{-1}+$ Spray of 19:19:19 @ $1 \%$ at 15, 30 and 45 DAS

9.00

$\mathrm{T}_{10}$-RPP (RDF+ $6 \mathrm{t} \mathrm{ha}^{-1}$ FYM+ Bio-fertilizer) + Spray of 19:19:19 @ $1 \%$ at 15, 30 and

9.31

45 DAS

$\mathrm{T}_{11}$-RPP (RDF+ $2.5 \mathrm{t} \mathrm{ha}^{-1}$ Vermicompost + Bio-fertilizer $)+$ Spray of 19:19:19 @ $1 \%$

9.56 at 15,30 and 45 DAS

$\mathrm{SE}(\mathbf{m}) \pm$

CD at $5 \%$ 
Table.3 Economics of foxtail millet production as influenced by nutrient management practices

\begin{tabular}{|c|c|c|c|c|}
\hline Treatment & $\begin{array}{l}\text { Cost of cultivation } \\
\quad\left(\text { Rs. ha }{ }^{-1}\right)\end{array}$ & $\begin{array}{l}\text { Gross Returns } \\
\quad\left(\text { Rs. } \text { ha }^{-1}\right)\end{array}$ & $\begin{array}{l}\text { Net Returns } \\
\left(\text { Rs. } \text { ha }^{-1}\right)\end{array}$ & $\mathbf{B}: \mathbf{C}$ \\
\hline$T_{1}$ : Absolute control & 19862 & 29459 & 9596 & 1.48 \\
\hline$T_{2}: \operatorname{RDF}\left(30: 15: 15 \mathrm{~kg} \mathrm{ha}^{-1}\right)$ & 21264 & 49379 & 28114 & 2.32 \\
\hline $\mathrm{T}_{3}:$ FYM $6 \mathrm{t} \mathrm{ha}^{-1}$ & 25662 & 42455 & 16792 & 1.65 \\
\hline $\mathrm{T}_{4}:$ Vermicompost $2.5 \mathrm{t} \mathrm{ha}^{-1}$ & 24662 & 46416 & 21754 & 1.88 \\
\hline $\mathrm{T}_{5}: \mathrm{RPP}\left(\mathrm{RDF}+6 \mathrm{t} \mathrm{ha}^{-1} \mathrm{FYM}+\mathrm{Bio}-\right.$ fertilizer $)$ & 27294 & 63209 & 35914 & 2.32 \\
\hline $\mathrm{T}_{6}: \mathrm{RPP}\left(\mathrm{RDF}+2.5 \mathrm{t} \mathrm{ha}^{-1}\right.$ Vermicompost + Bio-fertilizer $)$ & 26294 & 70317 & 44022 & 2.67 \\
\hline$T_{7}:$ RDF+ Foliar Spray of 19:19:19 @ $1 \%$ at 15, 30 and 45 DAS & 21549 & 53830 & 32280 & 2.50 \\
\hline $\begin{array}{l}\text { T8 }: \text { FYM } 6 \mathrm{t} \mathrm{ha}^{-1}+\text { Foliar Spray of 19:19:19 @ } 1 \% \text { at } 15,30 \text { and } \\
45 \text { DAS }\end{array}$ & 25947 & 57664 & 31717 & 2.22 \\
\hline $\begin{array}{l}\text { T }_{9}: \text { Vermicompost } 2.5 \mathrm{t} \mathrm{ha}^{-1}+\text { Foliar Spray of 19:19:19 @ } 1 \% \text { at } \\
\text { 15, } 30 \text { and } 45 \text { DAS }\end{array}$ & 24947 & 63219 & 38272 & 2.53 \\
\hline $\begin{array}{c}T_{10}: \text { RPP }\left(\text { RDF + } 6 \mathrm{t} \mathrm{ha}^{-1} \mathrm{FYM}+\text { Bio-fertilizer }\right)+\text { Foliar Spray of } \\
\text { 19:19:19 @ } 1 \% \text { at 15,30 and 45 DAS }\end{array}$ & 27579 & 77483 & 49904 & 2.81 \\
\hline $\begin{array}{c}\text { T }_{11}: \text { RPP }\left(\text { RDF + } 2.5 \mathrm{t} \mathrm{ha}^{-1} \text { Vermicompost + Bio-fertilizer }\right)+ \\
\text { Foliar Spray of 19:19:19 @ } 1 \% \text { at 15, } 30 \text { and } 45 \text { DAS }\end{array}$ & 26579 & 82677 & 56097 & 3.11 \\
\hline
\end{tabular}




\section{Quality parameter of foxtail millet}

The data on protein content differed significantly due to different treatment combinations and the results are shown in the Table 3 and Fig. 2

Among the different treatment combinations, the $\mathrm{RDF}\left(30: 15: 15 \mathrm{~kg} \mathrm{~N}: \mathrm{P}_{2} \mathrm{O}_{5}: \mathrm{K}_{2} \mathrm{O}^{-1}\right)+2.5$ $\mathrm{t} \mathrm{ha}^{-1}$ Vermicompost + Bio-fertilizer) + Foliar spray of 19:19:19 @ 1\% at 15, 30 and 45 DAS $\left(\mathrm{T}_{11}\right)$ recorded significantly higher protein content in seed $(9.56 \%)$. and which was on par with application of RDF (30:15:15 $\mathrm{kg} \mathrm{N}: \mathrm{P}_{2} \mathrm{O}_{5}: \mathrm{K}_{2} \mathrm{O}$ ha $\left.^{-1}\right)+6 \mathrm{tha}^{-1} \mathrm{FYM}+$ Biofertilizer) + Foliar spray of 19:19:19 @ 1\% at 15, 30 and 45 DAS $\left(\mathrm{T}_{10}\right)(9.31 \%), \mathrm{T}_{6}$ which received RPP $\left(\mathrm{RDF}+2.5 \mathrm{t} \mathrm{ha}^{-1}\right.$ Vermicompost + Bio-fertilizer). However, significantly lower dry matter accumulation was recorded in $\mathrm{T}_{1}(6.14 \%)$.

Higher the protein content was obtained with application of RDF (30:15:15 kg N: $\mathrm{P}_{2} \mathrm{O}_{5}: \mathrm{K}_{2} \mathrm{O}$ $\left.\mathrm{ha}^{-1}\right)+2.5 \mathrm{t} \mathrm{ha}^{-1}$ Vermicompost + Biofertilizer) + Foliar spray of 19:19:19 @ 1\% at 15,30 and 45 DAS. Increase in protein content of foxtail millet was mainly due to higher uptake of nitrogen and phosphorous through slow and continuous supply of $\mathrm{N}, \mathrm{P}$ and $\mathrm{K}$ through organic manures. Since phosphorus improves quality parameter by regulating the photosynthesis, respiration, root enlargement and carbohydrate metabolism, thus increased protein content. Similar results were found by Tanwar and Shaktawat (2003) in soyabean crop.

\section{Economics of foxtail millet production}

Economic analysis is one of the major criteria for evaluating efficient and economically available nutrient management practices. The data on cost of cultivation, gross returns, net returns and benefit cost ratio of foxtail millet production as influenced by various treatments is depicted in Table 4

\section{Cost of cultivation}

Significantly higher cost of cultivation was recorded with the application of $\mathrm{T}_{10}$ : $\mathrm{RDF}$ $\left(30: 15: 15 \mathrm{~kg} \mathrm{~N}: \mathrm{P}_{2} \mathrm{O}_{5}: \mathrm{K}_{2} \mathrm{O} \mathrm{ha}^{-1}\right)+2.5 \mathrm{tha}^{-1}$ Vermicompost + Bio-fertilizer) + Foliar spray of 19:19:19 @ 1\% at 15, 30 and 45 DAS (₹ $27579.5 \mathrm{ha}^{-1}$ ) followed by $\mathrm{T}_{5}$ (₹ $27294 \mathrm{ha}^{-1}$ ), $\mathrm{T}_{11}\left(\right.$ Rs $\left.26579 \mathrm{ha}^{-1}\right), \mathrm{T}_{6}\left(₹ 26294 \mathrm{ha}^{-1}\right), \mathrm{T}_{8}$ (₹ $25947 \mathrm{ha}^{-1}$ ), $\mathrm{T}_{3}$ (₹ $25662 \mathrm{ha}^{-1}$ ) and $\mathrm{T}_{9}$ (₹ 24947 ha $^{-1}$ ) compared to absolute control. Similar findings were reported by Patil and Udmale (2016).

\section{Gross returns}

Significantly higher gross returns was noticed in $\mathrm{T}_{11}: \mathrm{RDF}\left(30: 15: 15 \mathrm{~kg} \mathrm{~N}: \mathrm{P}_{2} \mathrm{O}_{5}: \mathrm{K}_{2} \mathrm{O} \mathrm{ha}^{-1}\right)+$ $2.5 \mathrm{t} \mathrm{ha}^{-1}$ Vermicompost + Bio-fertilizer) + Foliar spray of 19:19:19 @ 1\% at 15,30 and 45 DAS (₹ 82677. ha ${ }^{-1}$ ) followed by $\mathrm{T}_{10}$ (₹ $\left.77483 \mathrm{ha}^{-1}\right), \mathrm{T}_{6}\left(₹ 70317 \mathrm{ha}^{-1}\right), \mathrm{T}_{9}(₹ 63219$ $\left.\mathrm{ha}^{-1}\right), \mathrm{T}_{5}\left(₹ 63209 \mathrm{ha}^{-1}\right), \mathrm{T}_{8}\left(₹ 57664 \mathrm{ha}^{-1}\right), \mathrm{T}_{7}$ (₹ $53830 \mathrm{ha}^{-1}$ ) and $\mathrm{T}_{2}$ (₹ $49379 \mathrm{ha}^{-1}$ ) owing to higher economic yields obtained in these treatments, whereas, lower net returns was recorded in control due to lower yields.

Similar findings also reported by Ashoka et al., (2008) that, significantly highest gross return (Rs. 96,838 ha ${ }^{-1}$ ) were recorded with the application of RDF $+35 \quad \mathrm{~kg}$ Vermicompost, this could be mainly attributed to the higher yield of maize and chickpea crops.

\section{Net returns}

Significantly higher net returns was recorded with the application of $T_{11}:$ RDF (30:15:15 kg $\mathrm{N}: \mathrm{P}_{2} \mathrm{O}_{5}: \mathrm{K}_{2} \mathrm{O}$ ha $\left.^{-1}\right)+2.5 \mathrm{tha}^{-1}$ Vermicompost + Bio-fertilizer) + Spray of 19:19:19 @ 1\% at 15,30 and $45 \operatorname{DAS}\left(₹ 56097 \mathrm{ha}^{-1}\right.$ ) followed by $\mathrm{T}_{10}$ (₹ $49904 \mathrm{ha}^{-1}$ ), $\mathrm{T}_{6}$ (₹ $44022 \mathrm{ha}^{-1}$ ), $\mathrm{T}_{9}$ (₹ $38272 \mathrm{ha}^{-1}$ ), $\mathrm{T}_{5}$ (₹ $35914.5 \mathrm{ha}^{-1}$ ), $\mathrm{T}_{7}$ (₹ $\left.32280 \mathrm{ha}^{-1}\right)$ and $\mathrm{T}_{8}\left(₹ 31717 \mathrm{ha}^{-1}\right)$. 


\section{Benefit cost ratio (B:C)}

The interaction effects of foxtail millet as influenced by different nutrient management practices on benefit cost ratio were found non-significant. Significantly higher benefit cost ratio (3.11) was noticed in $\mathrm{T}_{11}$ : $\mathrm{RDF}$ $\left(30: 15: 15 \mathrm{~kg} \mathrm{~N}: \mathrm{P}_{2} \mathrm{O}_{5}: \mathrm{K}_{2} \mathrm{O} \mathrm{ha}^{-1}\right)+2.5 \mathrm{t} \mathrm{ha}^{-1}$ Vermicompost + Bio-fertilizer + Spray of 19:19:19@1\% at 15, 30 and 45 DAS) as compared to other treatments, viz., $\mathrm{T}_{10}(2.81)$, $\mathrm{T}_{6}$ (2.67), $\mathrm{T}_{9}$ (2.53), $\mathrm{T}_{7}(2.50), \mathrm{T}_{5}(2.32), \mathrm{T}_{2}$ (2.3) and $\mathrm{T}_{8}$ (2.22), Absolute control $\mathrm{T}_{1}(1.48)$.The results are in accordance with the findings of Jawadagi et al., (2012), Bekek (2014) in hybrid maize reported that the application of organic nutrient and inorganic nutrient management are mainly because higher gross return and benefit cost ratio.

In conclusion, low cost technology like organic sources of nutrients and use of Foliar sprays of NPK can help in augmenting yield and quality of produce. The Foliar sprays of 19:19:19@1\% at 15, 30 and 45 DAS increased yield to the upto $20.10 \%$.In modern agriculture, along with inorganic fertilizers, organic fertilizers are required for crops to get satisfactory yield and quality produce as nutrients are key elements for amino acid synthesis, protein synthesis, grain filling, etc., This study on effect of nutrient management in Foxtail millet is useful for deciding the suitable combination of nutrient sources for sustainable production and profitability.

\section{References}

Ashoka, P., Mudalagiriyappa, B. T., Pujari, P. S. and Desai, B. K., 2008, Effect of micronutrients with or without organic manures on yield and nutrient uotake of baby corn (Zea mays L.)-Chickpea (Cicer artietinum L.) sequence. Karnataka J. Agric. Sci., 21(4): 485487.
Bajpai, R. K., Chitale, S., Upadhyay, S. K. and Urkurkar, J. S., 2006, The long term studies on soil physico-chemical properties and productivity of ricewheat system as influenced by integrated nutrient management in Inceptisol of Chhattisgarh. J. Indian Soc. Soil Sci., 54: 24-29.

Balaji, N. B. and Yakadri, M., 2004, Effect of integrated nutrient management on yield of hybrid rice (Oryza sativa L.). J. Res., 32(2): 85- 89.

Bekek, Z., 2014, Evaluation of enriched farmyard manure and inorganic fertilizers profitability in hybrid maize (BH-140) production at west Hararghe zone, eastern Ethiopia. J. Genet. Environ. Resour. C., 2(1): 83-89.

Dosani, A. K., Talashilkar S. C. and Mehta V. B., 1999, Effect of poultry manure applied in combination with fertilizers on the yield, quality and nutrient uptake of groundnut. J. Indian Soc. Soil Sci., 47(1): 166-169.

Gupta, V., Sharma, R. S. and Vishvakarma, S. K., 2006, Long-term effect of integrated nutrient management on yield sustainability and soil fertility of rice (Oryza sativa L.) and wheat (Triticum aestivum L.) cropping system. Indian J. Agron., 51(12): 160-164.

Jadhao, S. M., Charjan, Y. D. and Naphade, P. S. 2002, Effect of organic manure and level of NPK on yield of sorghum and on micronutrient status of vertisol. J. soil crops., 12 (1): 147-150.

Jawadagi, R. S., Basavaraj, N., Patil, B. N., Naik, B. H. and Channappagoudar, B. B., 2012, Effect of different sources of nutrients on growth, yield and quality of onion (Allium cepa L.). Karnataka J. Agric. Sci., 25(2): 232-235.

Rahman, M. A., Chikushi, J., Saifizzaman, M. and Lauren, J. G., 2007, Rice straw mulching and nitrogen response of notill wheat following rice in Bangladesh. 
Field Crops Res. 91 (1): 71-81.

Tanwar, S. S. and Shaktawat, M. S., 2003, Influence of phosphorus sources, levels and solubilizers on yield, quality and nutrient uptake of soybean (Glycine $\max$ L.)- wheat (Triticum aestivum L.) cropping system of southern Rajasthan. Indian J. Agril. Sci., 73(1): 3-7.

Uddin, M. L., Thembinkosi, M., Christopher.
M. P. and Gabatshele, M., 2008, The growth and development of two pearl millet landraces as affected by organic manure application. Int. Curr. Microbiol. App. Sci., 3(9): 505-515

Vinall, H.N. 1924. Foxtail millet its culture and utilization in the united state. USDA Farmer Bulletin: 793.

\section{How to cite this article:}

Raviraja, S. R. Balanagoudar, S. N. Bhat, M. V. Ravi and Yadahalli, G. S. 2020. Effect of INM on Yield, Quality and Economics in Foxtail Millet (Setaria italica L.) in Black Soil. Int.J.Curr.Microbiol.App.Sci. 9(03): 2109-2116. doi: https://doi.org/10.20546/ijcmas.2020.903.241 